\title{
Control of ceramide-induced apoptosis by IGF-1: involvement of PI-3 kinase, caspase- 3 and catalase
}

\author{
T Kondo ${ }^{1}$, T Kitano ${ }^{1}$, K Iwai ${ }^{1}$, M Watanabe ${ }^{1}$, Y Taguchi ${ }^{1,2}$, \\ T Yabu ${ }^{1}$, H Umehara ${ }^{3}$, N Domae ${ }^{3}$, T Uchiyama ${ }^{1}$ and \\ T Okazaki*,1 \\ 1 Department of Hematology and Oncology, Graduate School of Medicine, Kyoto \\ University, 54 Syogoin-Kawaramachi, Sakyo-ku, Kyoto 606-8507, Japan \\ ${ }^{2}$ Laboratory of Membrane Biochemistry and Biophysics, Graduate School of \\ Biostudies, Kyoto University, Yoshida, Sakyo-ku, Kyoto 606-8501, Japan \\ 3 Department of Medicine, Osaka Dental University, 1-5-17 Otemae, Cyuoh-ku, \\ Osaka 540, Japan \\ * Corresponding author: T Okazaki, Department of Hematology and Oncology, \\ Graduate School of Medicine, Kyoto University, 54 Syogoin-Kawaramachi, \\ Sakyo-ku, Kyoto 606-8507, Japan \\ Tel \& Fax: +81-75-751-3154; E-mail: toshiroo@kuhp.kyoto-u.ac.jp
}

Received 3.7.01; revised 7.12.01; accepted 7.1.02

Edited by M Miura

\begin{abstract}
Insulin-like growth factor-1 (IGF-1) inhibited N-acetylsphingosine (C2-ceramide)-induced HL-60 cell apoptosis via relieving oxidative damage. This inhibitory action of IGF-1 was blocked by a phosphatidylinositol-3 (PI-3) kinase inhibitor wortmannin and enhanced by overexpression of the 110 catalytic subunit of PI-3 kinase. Either IGF-1 pretreatment or PI-3 kinase overexpression restored ceramide-depleted catalase function, and this restoration was inhibited by wortmannin. A catalase inhibitor 3-amino-1h-1, 2, 4-triazole (ATZ) blocked the inhibitory action of IGF-1 on ceramide-induced apoptosis, whereas exogenous purified catalase enhanced it. Ceramideactivated caspase-3 was inhibited by IGF-1/PI-3 kinase and enhanced by wortmannin, while the addition of a specific caspase-3 inhibitor DMQD-CHO significantly enhanced the restoration by IGF-1 of ceramide-depleted catalase function. Moreover, IGF-1 inhibited C2-ceramide-induced decrease of mitochondrial membrane potential, and increase of cytochrome $c$ release, caspase- 3 cleavage and caspase- 3 activity as judged by PhiPhiLux cleaving method. In summary, these results suggest that IGF-1/PI-3 kinase inhibited C2-ceramideinduced apoptosis due to relieving oxidative damage, which resulted from the inhibition of catalase by activated caspase-3. Cell Death and Differentiation (2002) 9, 682-692. DOI: 10.1038/ sj/cdd/4401019
\end{abstract}

Keywords: ceramide; insulin-like growth factor-1; phosphatidylinositol-3 kinase; catalase; caspase-3; oxidative stress; apoptosis

Abbreviations: IGF-1, insulin-like growth factor; PI-3, phosphatidylinositol-3; C2-ceramide, $\mathrm{N}$-acetylsphingosine; $\mathrm{ROS}$, reactive oxygen species; NAC. N-acetylcysteine; C6-ceramide, N-hexanoylsphingosine; GSH, glutathione; APAF-1, apoptotic protease activating factor-1

\section{Introduction}

The sphingolipid ceramide is known to be a pro-apoptotic lipid mediator, and apoptosis induced by many kinds of stresses is accompanied by an increase of intracellular ceramide. $^{1,2}$ It was reported that $\mathrm{N}$-hexanoylsphingosine (C6-ceramide) caused an increase of reactive oxygen species (ROS) probably by affecting electron transport in mitochondria, ${ }^{3}$ whereas $\mathrm{N}$-acetylsphingosine (C2-ceramide)induced apoptosis was suppressed by pretreatment with anti-oxidants such as $\mathrm{N}$-acetylcysteine (NAC) and glutathione $(\mathrm{GSH}) .^{4-8}$ These results suggest that ROS generation and oxidative damage are closely involved in apoptosis downstream of ceramide action. In addition, since ceramide was reported to release cytochrome $c$ from mitochondria and activate caspase-3 along with apoptotic protease activating factor-1 (Apaf-1) and pro caspase-9, caspase-3 seems to be another candidate of downstream signaling of ceramide. ${ }^{9,10}$ Indeed, both caspase-3 activation and apoptosis induced by C2-ceramide were blocked by caspase-3 inhibitors such as DEVD-CHO and DMQD$\mathrm{CHO} .{ }^{11-13}$ Although oxidative stress and ceramide are well known to activate caspase-3, it is, at present, poorly understood how ceramide increases oxidative damage through caspase-3 activation. ${ }^{14,15}$

On the other hand, several recent studies have revealed that insulin-like growth factor 1 (IGF-1) acted against pro-apoptotic stresses such as etoposide, doxorubicin, tumor necrosis factor- $\alpha, c-m y c$ overexpression and serum deprivation, ${ }^{16-18}$ and that a decrease of the IGF-1 receptor level or expression of dominant-negative IGF-1 receptor caused massive apoptosis in tumor transplantation models, ${ }^{19}$ suggesting a role of IGF-1 in apoptosis inhibition as well as cell survival. Regarding the mechanism by which IGF-1 inhibits ceramide-related apoptosis, it was shown that IGF-1 suppressed caspase-3 activation in retinal ganglion cells and cardiac muscle cells ${ }^{16,20}$ and ceramide generation probably through the inhibition of sphingomyelinase in MCF-7 cells. ${ }^{21,22}$ It was also reported that $\mathrm{C} 2-$ or $\mathrm{C} 6$-ceramide inhibited Akt kinase through $\mathrm{Pl}-3$ kinase inhibition, ${ }^{23,24}$ which occurred in association with caveolin 1 recruitment in raft microdomains, ${ }^{25}$ suggesting that $\mathrm{PI}-3$ kinase-dependent survival signal was inhibited by ceramide. However, it is still unclear whether survival signals induced by IGF-1/PI-3 kinase alter oxidative damage and caspase- 3 mediated by ceramide.

Therefore, we investigated here how IGF-1/PI-3 kinase affects C2-ceramide-induced caspase-3 activation, increase of oxidative damage judged by lipid peroxidation, and apoptosis. The results showed that IGF-1 inhibits ceramideincreased apoptosis and oxidative damage by restoring the action of ROS scavenger catalase through inhibition of caspase-3 in a PI-3 kinase-dependent manner. 


\section{Results}

\section{Inhibitory action of IGF-1 on C2-ceramide-induced} apoptosis and lipid peroxidation

The proportion of apoptotic cells with nuclear condensation and fragmentation, as judged by the DAPI method, increased to $60 \%$ after $24 \mathrm{~h}$ of $5 \mu \mathrm{M} \mathrm{C2-ceramide} \mathrm{treatment} \mathrm{in} \mathrm{serum-}$ free medium, and pretreatment with IGF-1 inhibited the ceramide induced apoptosis in a time- and dose-dependent manner (Figure 1A,B). The proportion of apoptotic cells induced by $5 \mu \mathrm{M}$ C2-ceramide decreased from 60 to $37 \%$ and to $22 \% 24 \mathrm{~h}$ after treatment with 100 and $1000 \mathrm{ng} / \mathrm{ml}$ IGF-1, respectively. The similar inhibition by IGF-1 of ceramide-induced apoptosis was also detected when apoptosis was examined by the extent of annexin $\mathrm{V}$ binding ability to the cell surface outer membrane. The mean fluorescence intensity of annexin $\mathrm{V}$ and the proportion of annexin $\mathrm{V}$ positive cells induced by $5 \mu \mathrm{M}$ C2-ceramide decreased from 120 to $78 \%$ and from 68 to $35 \%$ by pretreatment with $100 \mathrm{ng} / \mathrm{ml}$ IGF-1, respectively (Figure 1C). In addition, increase of ceramide-induced lipid peroxidation, which was judged by detecting a decrease of fluorescence of cis-parinaric acid (CPA), was suppressed from 158 to $123 \%$ and to $110 \%$ of control level by pretreatment with 100 and $1000 \mathrm{ng} / \mathrm{ml}$ IGF-1, respectively (Figure 1D). These results suggested that IGF-1 exerted its anti-apoptotic effect against ceramide-induced apoptosis through inhibiting oxidative damage.

\section{Effects of wortmannin on the inhibition by IGF-1 of C2-ceramide-induced apoptosis and lipid peroxidation}

To investigate whether the activation of $\mathrm{PI}-3$ kinase is required for mediating the inhibitory action of IGF-1, we examined the effect of a specific PI-3 kinase inhibitor, wortmannin, on the inhibition by IGF-1 of C2-ceramide-induced apoptosis and lipid peroxidation. While the per cent of apoptosis induced by $5 \mu \mathrm{M}$ C2-ceramide decreased from 59 to $30 \%$ in the presence of $100 \mathrm{ng} / \mathrm{ml}$ IGF-1, pretreatment with $20 \mathrm{nM}$ wortmannin restored the per cent of apoptosis from 30 to $64 \%$ despite the presence of IGF-1 (Figure $2 \mathrm{~A}$ ). In addition, the level of $5 \mu \mathrm{MC2}$ ceramide-increased lipid peroxidation was inhibited from 158 to $118 \%$ of control level in the presence of $100 \mathrm{ng} / \mathrm{ml} \mathrm{IGF-1,} \mathrm{but}$ restored again to $159 \%$ of control level by pretreatment with $20 \mathrm{nM}$ wortmannin (Figure 2B). Thus, these results suggested that the inhibition by IGF-1 of ceramide-induced apoptosis and lipid peroxidation was dependent on $\mathrm{PI}-3$ kinase activation. To confirm this notion, we next examined whether activation of $\mathrm{PI}$ 3 kinase by overexpressing its gene suppressed ceramideinduced apoptosis and lipid peroxidation. For this purpose, $\mathrm{HL}-$ 60 cells were transfected with a transient expression plasmid

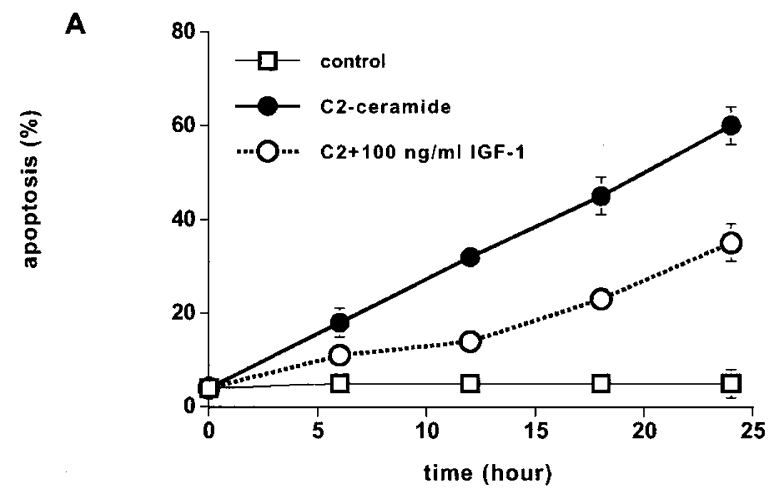

C
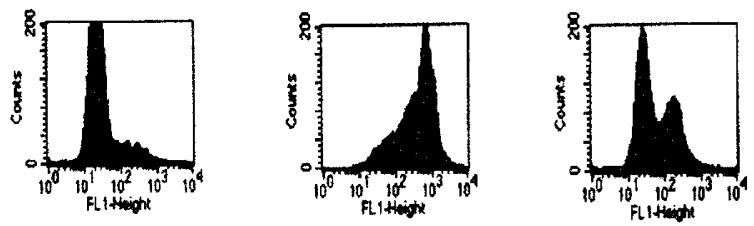

Control

C2-ceramide

IGF-1+C2

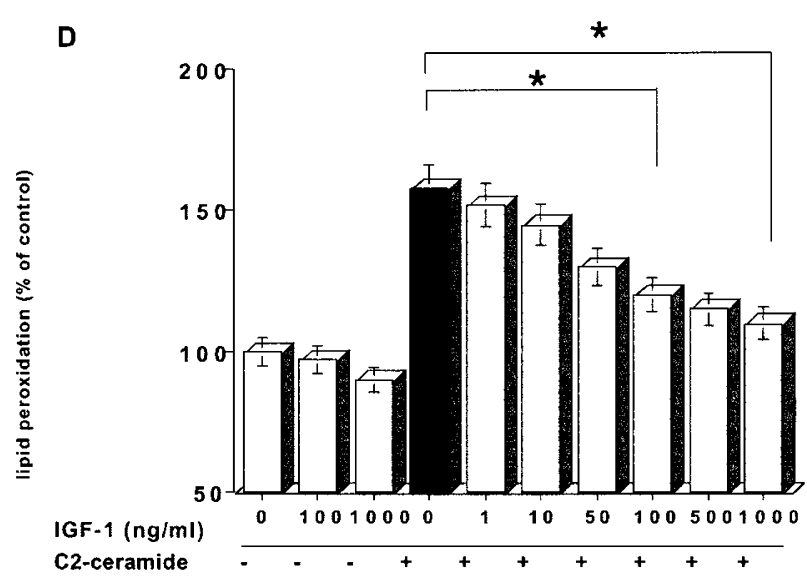

Figure 1 Inhibitory action of IGF-1 on ceramide-induced apoptosis and lipid peroxidation. HL-60 cells were pretreated with $100 \mathrm{ng} / \mathrm{ml}(\mathbf{A}$ and $\mathbf{C})$ or various concentrations of IGF-1 (B and D) for 30 min before treatment with $5 \mu \mathrm{M} \mathrm{C2-ceramide} \mathrm{in} \mathrm{serum-free} \mathrm{media,} \mathrm{and} \mathrm{harvested} \mathrm{at} \mathrm{various} \mathrm{times} \mathrm{(A)} \mathrm{or} 24 \mathrm{~h}$ after treatment (B, C and $\mathbf{D})$. Apoptosis was judged by the DAPI staining method (A and $\mathbf{B})$ or annexin V binding ability (C), and lipid peroxidation was measured by the cis-parinaric acid (CPA) fluorescence reducing method as described under 'Materials and Methods' (D). The results are the averages of at least three independent experiments (A, B and $\mathbf{D})$ or the representative of three different experiments (C). The bars indicate 1 S.D. The significance of differences of apoptosis levels between the treatments with or without IGF-1 was determined by ANOVA test. *Indicates $P<0.01$ (B and D) 

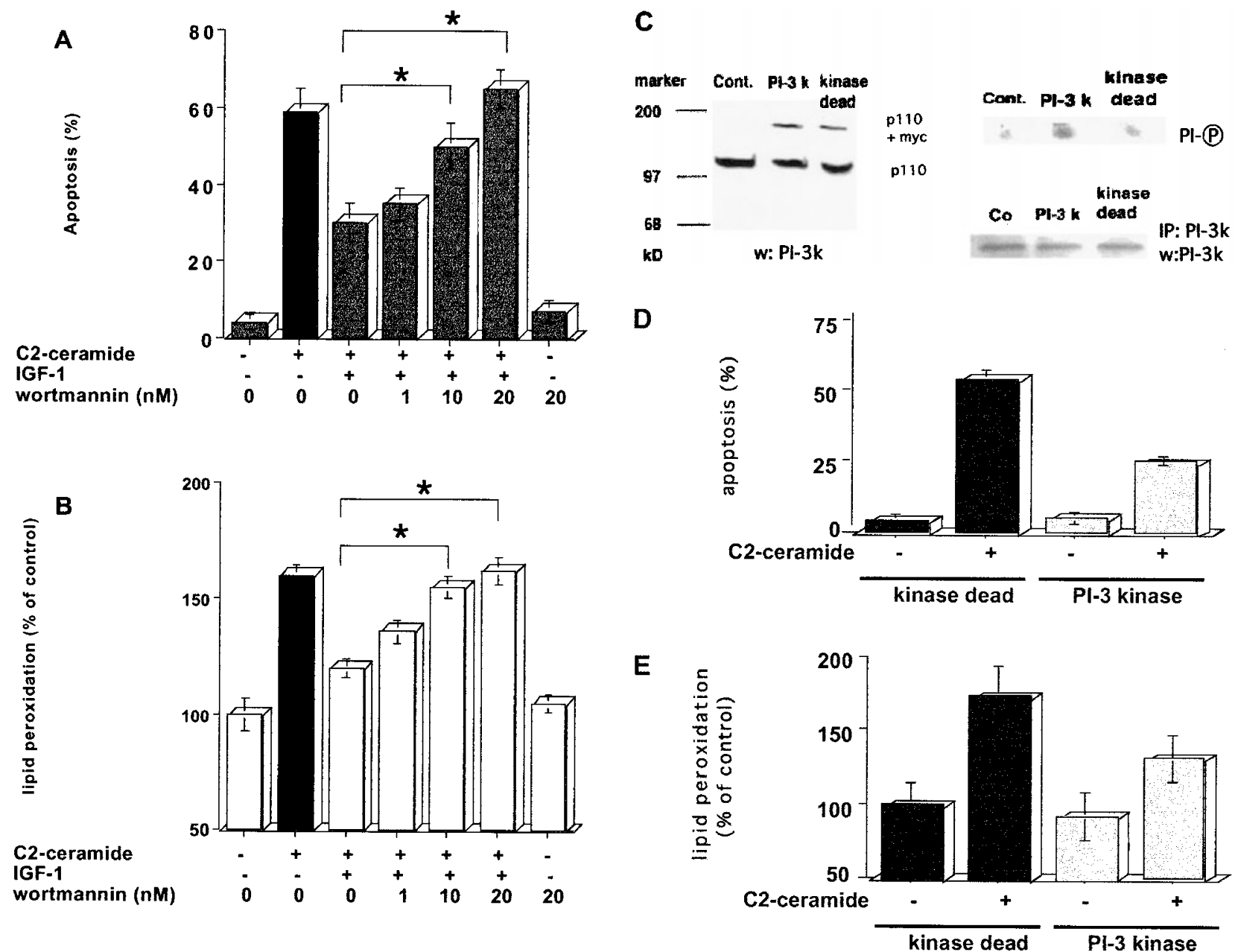

Figure 2 Effects of wortmannin and overexpression of PI-3 kinase on the inhibitory action of IGF-1 on ceramide-induced apoptosis and lipid peroxidation. HL-60

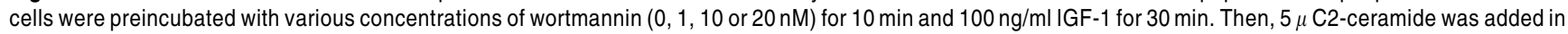
serum-free media for $24 \mathrm{~h}$. Apoptosis (A) and lipid peroxidation (B) were judged by the DAPI staining method and the reducing ability of cis-parinaric acid (CPA)generated fluorescence, respectively, as described under Materials and Methods. HL-60 cells were transiently transfected without (control) or with plasmid containing myc-tagged p110 of Pl-3 kinase gene (PI-3k) or myc-tagged p110 of Pl-3 kinase-dead gene (kinase dead) by electroporation (C, left panel). After immunoprecipitation with anti-p110 of PI-3 kinase antibody PI-3 kinase activity was assessed by phosphorylating PI (C, right upper panel), and equal amount of immunoprecipitated PI-3 kinase protein was confirmed by Western blotting analysis with anti-PI-3 kinase antibody after immunoprecipitation (C, right lower panel). $\mathrm{PI}-3 \mathrm{k}$ and kinase-dead cells were incubated in $10 \% \mathrm{FCS}$-containing media for $48 \mathrm{~h}$ after electroporation, and then treated with $20 \mu \mathrm{M} \mathrm{C2-ceramide} \mathrm{for} 24 \mathrm{~h}$. Apoptosis (D) and lipid peroxidation (E) were judged as described in Figure 1. The results are the averages of at least three independent experiments (A, B, D and E) or the representative of three different experiments (C). The bars indicate 1 S.D. The significance of differences of apoptosis and lipid peroxidation levels between the treatments with or without wortmannin was determined by ANOVA test. *Indicates $P<0.01$ (A and B). Statistical significance by ANOVA test was $P<0.05$ for the difference of increase of apoptosis and lipid peroxidation between kinase-dead and PI-3k cells ( $\mathbf{D}$ and $\mathbf{E})$

encoding the catalytic $\mathrm{p} 110$ subunit of $\mathrm{PI}-3$ kinase gene with a myc tag at its C-terminus, or with an expression plasmid encoding a gene point-mutated at the ATP-binding site of the p110 subunit, which expressed an enzymatically inactive PI-3 kinase protein, as the control. As shown in Figure 2C, PI-3 kinase-overexpressing (PI-3k) cells and $\mathrm{Pl}-3$ kinase-dead (kinase dead) cells expressed similar amount of Pl-3 kinase protein, but the activity of $\mathrm{Pl}-3$ kinase was much higher in PI-3k cells than kinase dead cells. Ceramide-induced apoptosis and lipid peroxidation less increased in $\mathrm{PI}-3 \mathrm{k}$ cells than in kinasedead cells (Figure 2D, $P<0.01$ ). Apoptosis and lipid peroxidation induced by $20 \mu \mathrm{M} \mathrm{C2}$-ceramide for $24 \mathrm{~h}$ in $10 \%$ FCS less increased in PI-3k cells ( $34 \pm 3 \%$ and $136 \pm 17 \%$, respectively) as compared to kinase-dead cells $(53 \pm 4 \%$ and $172 \pm 20 \%$, respectively). These results further confirmed that IGF-1 action against $\mathrm{C} 2$-ceramide-induced apoptosis and oxidative damage was mediated through $\mathrm{PI}-3$ kinase.

\section{IGF-1 did not inhibit C2-ceramide-induced long- chain ceramide generation}

When we examined the content of physiological long-chain ceramide, which was measured by a DGK assay, after treatment with $\mathrm{C} 2$-ceramide in $\mathrm{HL}-60$ cells, we found that $5 \mu \mathrm{M} \mathrm{C2}$-ceramide increased the content of intracellular longchain ceramide in a time-dependent manner (Figure 3). As shown in Figure 1, IGF-1 at a concentration of $100 \mathrm{ng} / \mathrm{ml}$ inhibited C2-ceramide-induced apoptosis and oxidative 


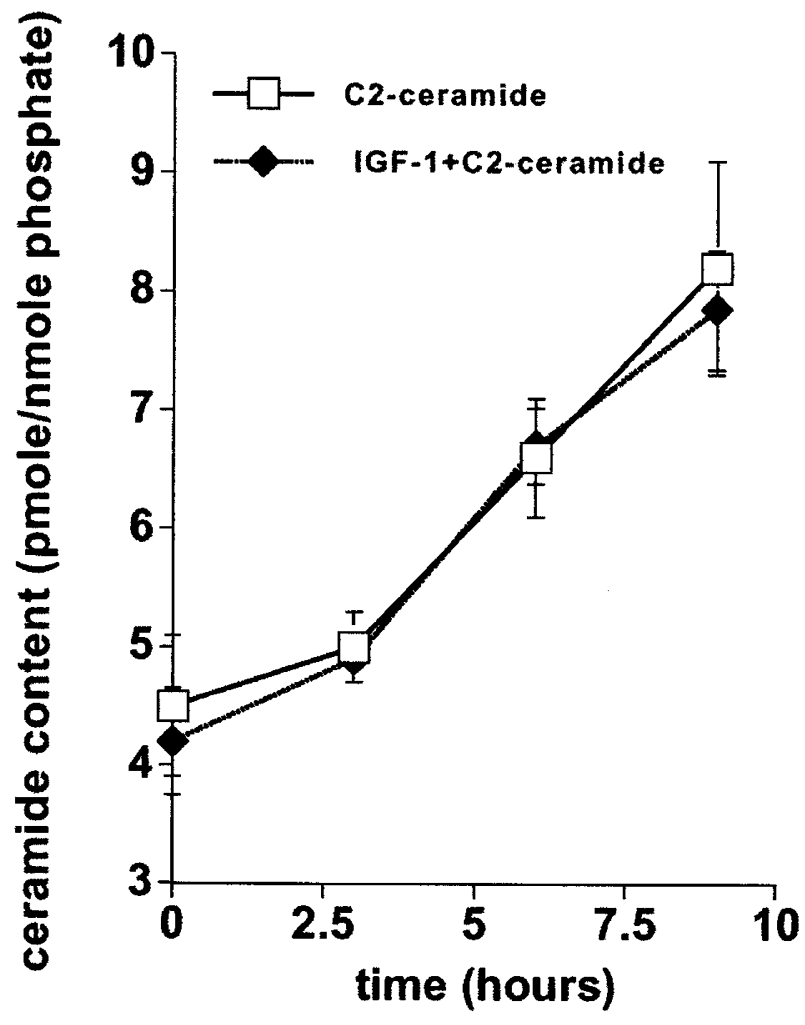

Figure 3 No inhibition by IGF-1 of C2-ceramide-induced long-chain ceramide generation. $\mathrm{HL}-60$ cells were treated with $5 \mu \mathrm{M} \mathrm{C2}$-ceramide in the presence or

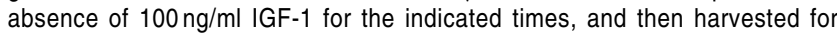
measuring ceramide levels by the DAG kinase method as described in Materials and Methods. The results are the averages from at least three independent experiments. The bars indicate 1 S.D.

damage, but did not decrease the content of long-chain ceramide at all, suggesting that the inhibitory action of IGF-1 against exogenous C2-ceramide was exerted downstream of intracellular ceramide action.

\section{IGF-1 restored C2-ceramide-depleted catalase function in a PI-3 kinase-dependent manner}

We investigated the involvement of ROS scavengers such as glutathione peroxidase (GPx), glutathione (GSH) and catalase in C2-ceramide-induced apoptosis. C2-ceramide decreased catalase activity in a dose-dependent manner, but did not affect GPx activity or GSH content in HL-60 cells (data not shown). As shown in Figure 4A,B, $5 \mu \mathrm{M}$ C2 ceramide in a serum-free condition decreased the catalase content judged by Western blotting analysis in a timedependent manner, and the addition of $100 \mathrm{ng} / \mathrm{ml}$ IGF-1 restored the catalase depletion by $\mathrm{C} 2$-ceramide, and pretreatment with $20 \mathrm{nM}$ wortmannin inhibited the restoration by IGF-1 of ceramide-depleted catalase content. Similarly, the activity of catalase, which was decreased from 78 to $37 \mathrm{U} / \mathrm{mg}$ protein after $24 \mathrm{~h}$ of $\mathrm{C} 2$-ceramide treatment, was

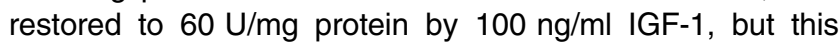
restoration of catalase activity was decreased to $35 \mathrm{U} / \mathrm{mg}$ protein by the addition of wortmannin $(P<0.01)$. IGF-1 alone did not affect catalase activity, while $20 \mathrm{nM}$ wortmannin
A

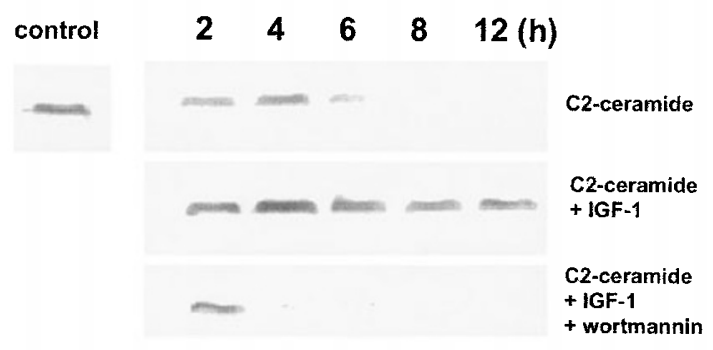

B

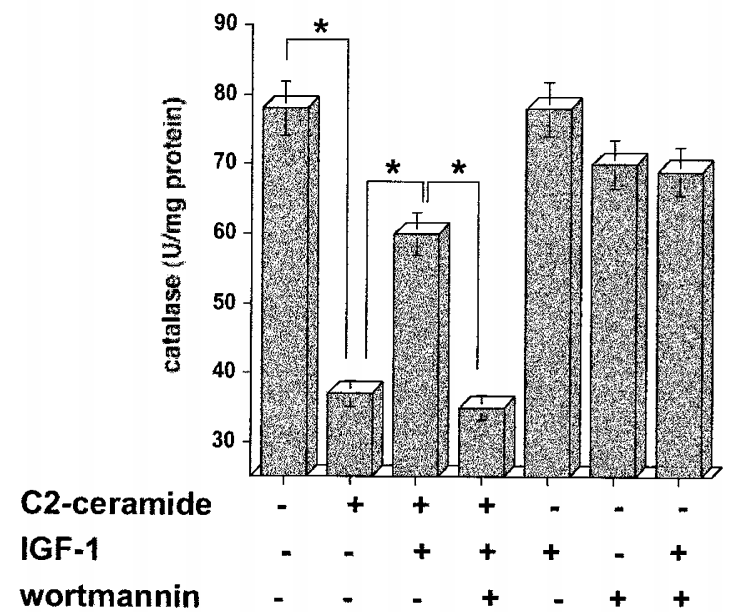

Figure 4 Inhibitory action of IGF-1 on ceramide-depleted catalase, and its inhibition by wortmannin. HL-60 cells were preincubated in the presence or absence of $20 \mathrm{nM}$ wortmannin for $10 \mathrm{~min}$ and followed by treatment with $100 \mathrm{ng} / \mathrm{ml}$ IGF-1 for $30 \mathrm{~min}$. Then, the cells were treated with or without $5 \mu \mathrm{M}$ C2-ceramide and harvested various times $(\mathbf{A} ; 0,2,4,6,8$ and $12 \mathrm{~h}, \mathbf{B} ; 24 \mathrm{~h})$ after treatment. Western blotting analysis for the amount of catalase $(\mathbf{A})$ and measurement of catalase activity (B) were performed as described in 'Materials and Methods'. The results $(\mathbf{A})$ are representative of two independent experiments. The results (B) are the averages from three independent experiments, and the bars indicate 1 S.D. The significance of differences of catalase activity levels between the treatments was determined by ANOVA test. *Indicates $P<0.01$ (B)

slightly decreased its activity. In addition, the depletion of catalase content was inhibited by $\mathrm{C} 2$-ceramide in $\mathrm{PI}-3$ kinase-overexpressing cells, but not in the kinase dead cells, while $\beta$-actin and protein level were equally detected in both cells (Figure 5A). Treatment with $20 \mu \mathrm{M}$ C2-ceramide in 10\% FCS condition catalase saw activity decreased from 88 to $55 \mathrm{U} / \mathrm{mg}$ protein in PI-3k cells and from 78 to $27 \mathrm{U} / \mathrm{mg}$ protein in the kinase-dead cells (Figure $5 \mathrm{~B}, P<0.01$ ). These results suggest that IGF-1 prevented the depletion of catalase by ceramide at both the protein level and activity levels in a PI-3 kinase-dependent manner.

A catalase inhibitor, ATZ, and exogenous, purified catalase modulated the inhibition by IGF-1 of C2ceramide-induced apoptosis and lipid peroxidation

To confirm the role of catalase in the inhibition by IGF-1 of ceramide-induced apoptosis and lipid peroxidation, we 
A

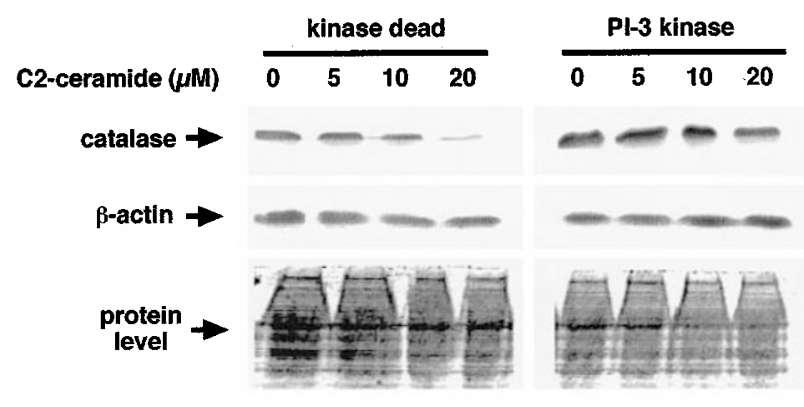

B

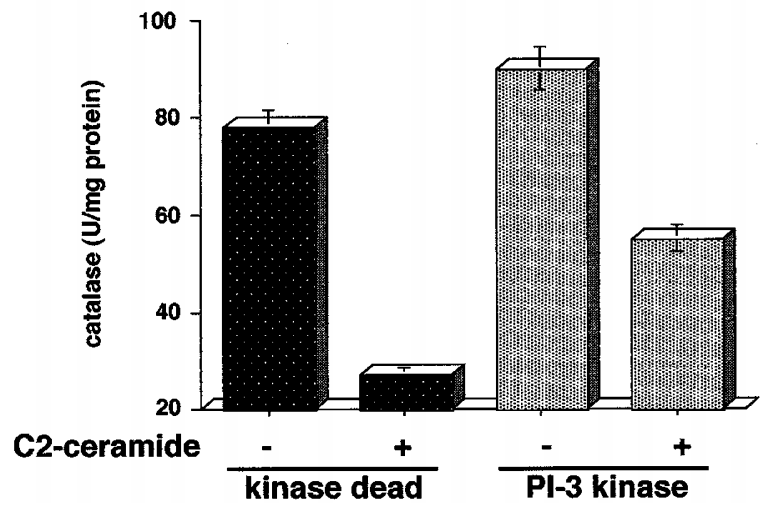

Figure 5 Inhibitory effect of overexpression of $\mathrm{PI}-3$ kinase on ceramidedepleted catalase. PI-3 kinase-overexpressing HL-60 cells (PI-3k) and kinasedead $\mathrm{HL}-60$ cells (kinase dead) were made as described in Figure 2. PI-3K and kinase-dead cell were treated with various concentrations of C2-ceramide (A $0,5,10$ or $20 \mu \mathrm{M}, \mathrm{B} ; 0$ or $20 \mu \mathrm{M}$ ) for $24 \mathrm{~h}$ in $10 \%$ FCS-containing media. Western blotting analysis for catalase and $\beta$-actin protein, and Coomassie blue staining to confirm equal load of proteins $(\mathbf{A})$ and measurement of catalase activity (B) were performed as described in Materials and Methods. The results $(\mathbf{A})$ are the representative of two independent experiments. The results $(B)$ are the averages from at least three independent experiments, and the bars indicate 1 S.D. Statistical significance by ANOVA test was $P<0.05$ for the difference of decrease of catalase activity between kinase-dead cell and $\mathrm{PI}-3 \mathrm{~K}$ cells $(\mathrm{B})$

examined whether a catalase inhibitor, ATZ, and exogenous, purified catalase modulated IGF-1 action against C2ceramide. ATZ prevented the inhibitory action of IGF-1 on $5 \mu \mathrm{M}$ C2-ceramide-induced apoptosis while purified catalase enhanced it in a dose-dependent manner (Figure 6A). Similarly, ATZ prevented the inhibition by IGF-1 of C2ceramide-induced lipid peroxidation while purified catalase enhanced it in a dose-dependent manner (Figure 6B). These results suggest that the extent of catalase activity was related to the inhibitory action of IGF-1 on ceramideinduced apoptosis and oxidative damage.

\section{Inhibition by IGF-1 of C2-ceramide-induced decrease of mitochondrial membrane potential, and increase of cytosolic release of cytochrome $c$, caspase- 3 cleavage and caspase- 3 activity}

We examined whether IGF-1 inhibited ceramide-induced apoptosis upstream of caspase-3 activation. As shown in
A

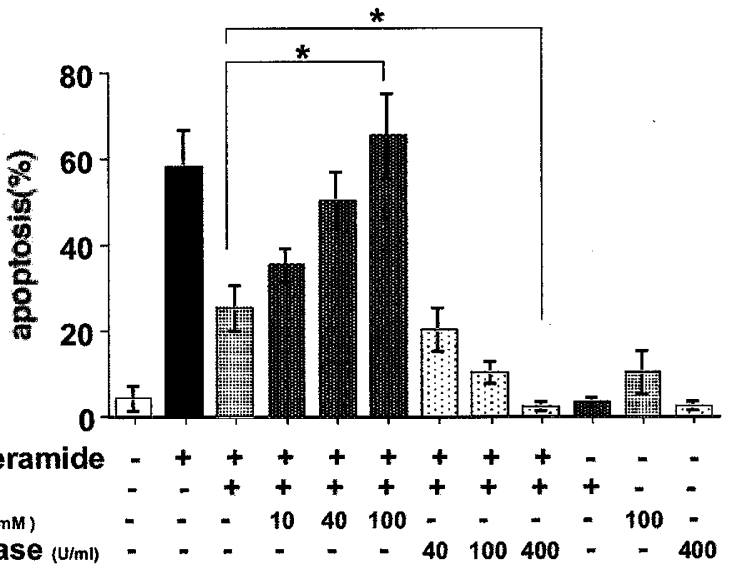

B

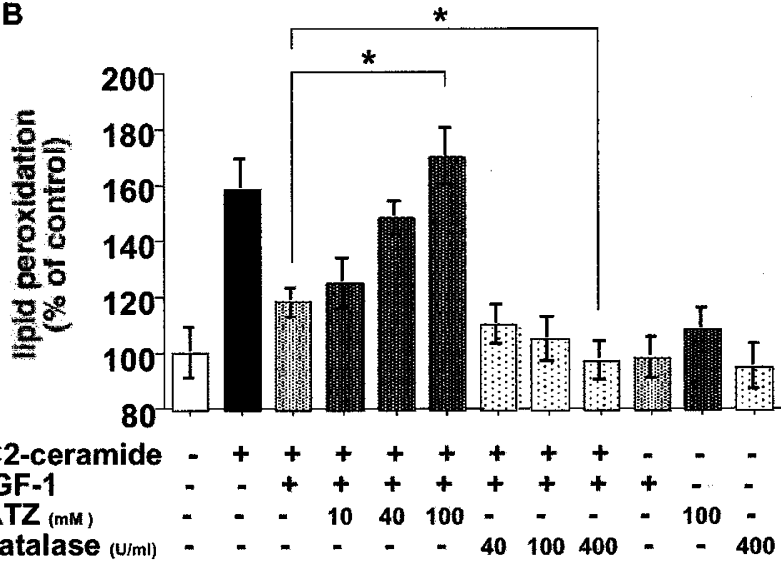

Figure 6 Modulation by catalase inhibitor, ATZ, and purified exogenous catalase of the inhibitory action of IGF-1 on ceramide-induced apoptosis and lipid peroxidation. $\mathrm{HL}-60$ cells were treated simultaneously with $\mathrm{C2}$-ceramide and IGF-1 in the presence of various concentrations of ATZ $(0,10,40$ or $100 \mathrm{mM})$ or purified catalase $(0,40,100$ or $400 \mathrm{U} / \mathrm{ml})$. Apoptosis $(A)$ and lipid peroxidation (B) were judged $24 \mathrm{~h}$ after treatment as described in Materials and Methods. The results are the averages from at least three independent experiments, and the bars indicate 1 S.D. The significance of differences of apoptosis and lipid peroxidation levels between the treatments with or without ATZ and purified catalase was determined by ANOVA test. *Indicates $P<0.01$

Figure 7, an intensification of caspase-3-related signals such as mitochondrial membrane potential, cytochrome $c$ release from mitochondria to cytosol, caspase-3 cleavage and realtimed caspase- 3 activation by PhiPhiLux-using method were all detected in $5 \mu \mathrm{M} \mathrm{C2}$-ceramide-induced apoptosis. These increases of caspase-3-related signals were inhibited in the presence of $100 \mathrm{ng} / \mathrm{ml} \mathrm{IGF-1,} \mathrm{and} \mathrm{these} \mathrm{inhibitory} \mathrm{action} \mathrm{of}$ IGF-1 was suppressed by pretreatment with $20 \mathrm{nM}$ wortmannin. These results suggest that IGF-1 inhibited caspase3 activation by augmenting mitochondrial function to restore ceramide-induced apoptosis.

\section{A caspase-3 inhibitor DMQD-CHO augmented the inhibition by IGF-1 of C2-ceramide depleted catalase function}

Under conditions in which IGF-1 inhibited C2-ceramideinduced apoptosis and lipid peroxidation, the activation of 
A

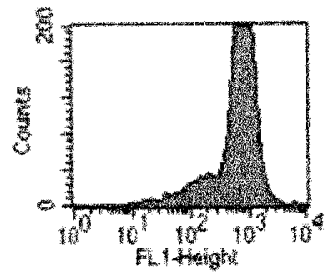

Control

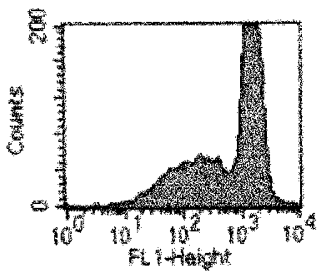

$\mathrm{IGF}-1+\mathrm{C} 2$

C

$\begin{array}{llll}0 & 4 & 12 & \text { (h) }\end{array}$

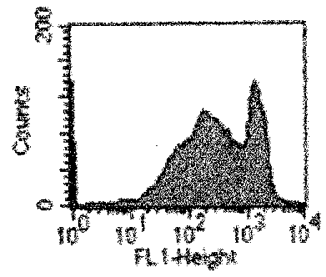

C2-ceramide

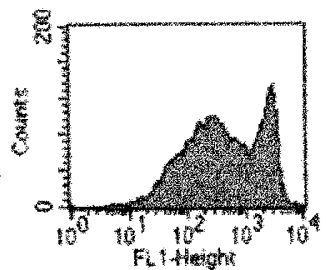

wort + IGF $-1+C 2$
B

$04812(h) \quad 04812(h)$

C2-ceramide

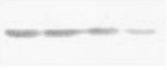

IGF-1+C2-ceramide

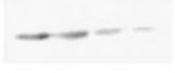

mitochondria cytochrome C

cytosolic cytochrome C

D
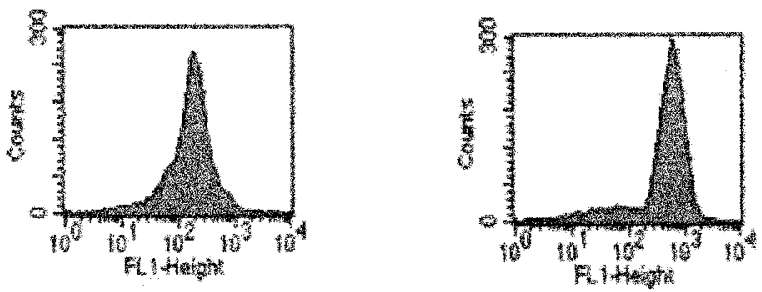

wort+IGF-1+C2-cer

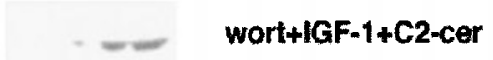

Control

C2-ceramide

IGF-1+C2-ceramide

wort+|GF-1+C2-cer

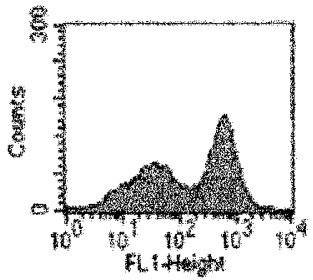

$\mathrm{IGF}=1+\mathrm{C} 2$

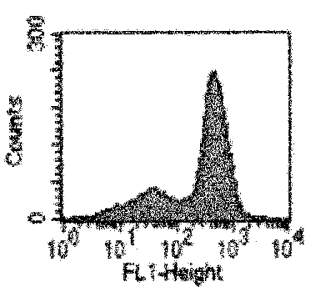

wort $+1 \mathrm{GF}-1+\mathrm{C} 2$

Figure 7 Inhibitory action of IGF-1 on ceramide-induced mitochondrial transmembrane potential, cytosolic release of cytochrome $c$, caspase-3 cleavage and caspase-3 activity, and its inhibition by wortmannin. HL-60 cells were preincubated in the presence or absence of $20 \mathrm{nM}$ wortmannin for 10 min and followed by treatment with $100 \mathrm{ng} / \mathrm{ml} \mathrm{IGF-1} \mathrm{for} 30 \mathrm{~min}$. Then, the cells were treated with $5 \mu \mathrm{M} \mathrm{C} 2$-ceramide for $24 \mathrm{~h}(\mathbf{A}$ and $\mathbf{D})$ or the indicated times $(\mathbf{B}$ and $\mathbf{C})$. Measurement of mitochondrial transmembrane potential using $\mathrm{DiOC}_{6}(\mathbf{A})$, cytosolic release of cytochrome $c$ from mitochondria $(\mathbf{B})$ and caspase-3 cleavage by Western blotting analysis (C) and real-time detection of caspase-3 activity by PhiPhilux G1D2 method (D) were performed as described in Materials and Methods. The results are representative of three independent experiments

caspase-3 activity was examined. As shown in Table 1, when $5 \mu \mathrm{M}$ C2-ceramide increased caspase-3 activity judged by DEVD-cleaving activity from 40 to $315 \mathrm{pmol} / \mathrm{mg}$ protein $/ \mathrm{min}$, $100 \mathrm{ng} / \mathrm{ml}$ IGF-1 inhibited an increase of its activity to $180 \mathrm{pmol} / \mathrm{mg}$ protein/min. A specific caspase-3 inhibitor DMQD-CHO, $100 \mu \mathrm{M}$ of which showed a significant inhibition of ceramide-activated caspase-3 from 315 to $175 \mathrm{pmol} / \mathrm{mg}$ protein/min $(P<0.01)$ Similarly, DMQD-CHO enhanced the inhibitory action of $100 \mathrm{ng} / \mathrm{ml} \mathrm{IGF-1} \mathrm{on} 5 \mu \mathrm{M}$ C2-ceramideinduced lipid peroxidation and apoptosis (from 121 to $108 \%$, $P<0.05$ and from 29 to $12 \%, P<0.01$, respectively). At the same condition DMQD-CHO also enhanced the inhibitory action of IGF-1 on C2-ceramide depleted catalase. Pretreatment with $100 \mu \mathrm{M}$ DMQD-CHO enhanced the restoration by 
Table 1 Table DMQD-CHO augmented the inhibitory action of IGF-1 on ceramide-increased caspase-3 activity, lipid peroxidation and apoptosis

\begin{tabular}{|c|c|c|c|}
\hline Treatment & $\begin{array}{c}\text { Caspase-3 } \\
(\mathrm{pmol} / \mathrm{mg} \\
\text { protein } / \mathrm{h})\end{array}$ & $\begin{array}{c}\text { Lipid } \\
\text { peroxidation } \\
\text { (\% of control) } \\
\end{array}$ & $\begin{array}{c}\text { apoptosis } \\
(\%)\end{array}$ \\
\hline Control & $40 \pm 20$ & $100 \pm 8$ & $4 \pm 1$ \\
\hline $5 \mu \mathrm{M} \mathrm{C2}$-ceramide & $315 \pm 25$ & $165 \pm 10$ & $70 \pm 8$ \\
\hline $\begin{array}{l}5 \mu \mathrm{M} \mathrm{C} \text {-ceramide + } \\
100 \mathrm{ng} / \mathrm{ml} \mathrm{IGF-1}\end{array}$ & $180 \pm 157$ & $121 \pm 57$ & $29 \pm 67$ \\
\hline $\begin{array}{l}5 \mu \mathrm{M} \text { C2-ceramide }+ \\
100 \mu \mathrm{M} \text { DMQD-CHO }\end{array}$ & $175 \pm 20$ & $140 \pm 8$ & $45 \pm 4$ \\
\hline $\begin{array}{l}5 \mu \mathrm{M} \text { C2-ceramide + } \\
100 \mathrm{ng} / \mathrm{ml} \text { IGF-1 + } \\
100 \mu \mathrm{M} \text { DMQD-CHO }\end{array}$ & $70 \pm 10$ & $108 \pm 5$ & $12 \pm 2$ \\
\hline
\end{tabular}

$\mathrm{HL}-60$ cells were treated with $5 \mu \mathrm{M}$ C2-ceramide in the presence of $100 \mathrm{ng} / \mathrm{m}$ IGF-1, $100 \mu \mathrm{M}$ DMQD-CHO for $48 \mathrm{~h}$ in serum-free media, and apoptosis, lipid peroxidation, and DEVDase activity were measured as described in Experimenta Procedures. The values are the means \pm 1 S.D. from at least three different experiments. The significance of differences of caspase-3, lipid peroxidation and apoptosis levels between the treatments with and without DMQD-CHO was determined by Student $t$-test. * and ** indicate $P<0.05$ and $P<0.01$, respectively.

$100 \mathrm{ng} / \mathrm{ml}$ IGF-1 of ceramide-decreased catalase activity from 53 to $74 \mathrm{U} / \mathrm{mg}$ protein (Figure $8 \mathrm{~A}, P<0.01$ ). The enhancement of catalase at the catalase protein level was also detected by DMQD-CHO (Figure $8 \mathrm{~B}$ ). These results suggest that the regulation of catalase function by caspase-3 plays an important role in the inhibition by IGF-1 upstream of ceramide induced oxidative damage and apoptosis.

\section{Discussion}

IGF-1 promotes cell survival at physiological concentrations in pro-apoptotic conditions such as interleukin-3 withdrawal, cmyc overexpression and potassium deprivation. ${ }^{18,26,27}$ Conversely, functional impairment of the IGF-1 receptor using dominant-negative IGF-1 receptor and antisense strategies induced massive apoptosis and delay of tumor growth, respectively. ${ }^{19,28}$ HL-60 cells, which we used in this study, express IGF-1 receptor, and show IGF-1-dependent cell survival in serum-free medium. ${ }^{29}$ It has been reported that many compounds, such as 4-hydroxy-2-nonenal, cupric nitrilotriacetate, TNF- $\alpha$ and IL-1 $\alpha$, induce apoptosis through increasing lipid peroxidation. ${ }^{15,30,31}$ In contrast, the suppression of lipid peroxidation inhibited $\mathrm{TNF}-\alpha-$ or $\mathrm{NO}$-induced apoptosis. $^{32,33}$ These data suggest that oxidative damage, judged by lipid peroxidation, may be intimately involved in the inhibition of apoptosis by IGF-1. Since ceramide-induced increase of ROS generation judged by $2^{\prime}, 7^{\prime}$-dichlorofluorescein diacetate (DCFH-DA) method was significant but faint (data not shown), we decided to measure lipid peroxidation as a marker for accumulation of oxidative damage. As shown in Figure 1, IGF-1 inhibited C2-ceramide-induced HL-60 cell apoptosis through inhibiting oxidative damage in a dose- and time-dependent manner. In addition, the inhibition of lipid peroxidation and apoptosis by IGF-1 was shown to be dependent on PI-3 kinase signalling because the inhibitory
A

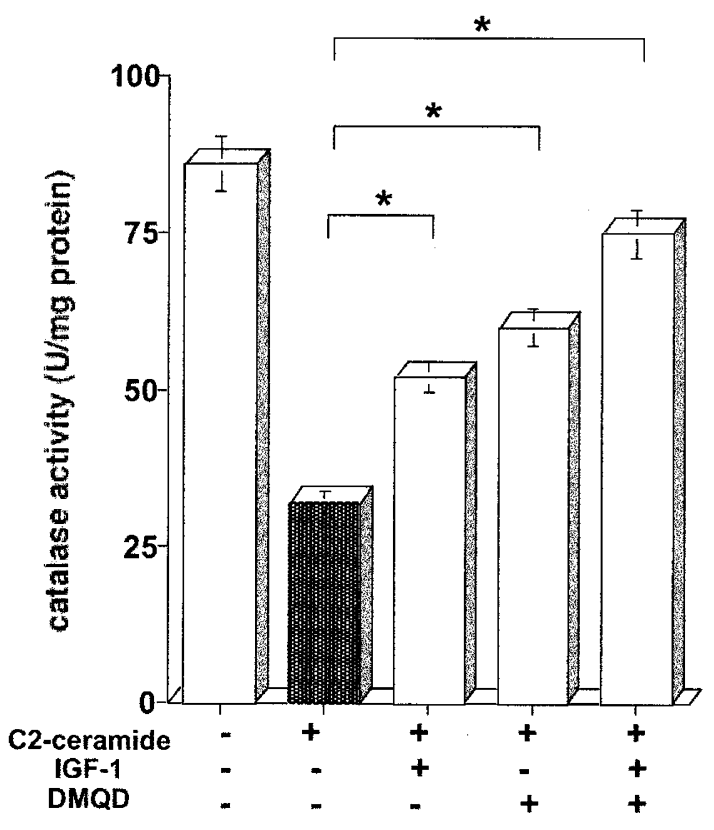

$\mathbf{B}$

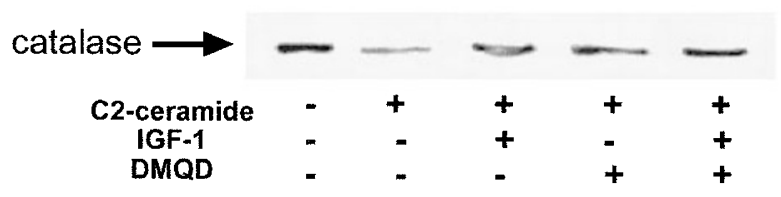

Figure 8 Augmentation by a caspase-3 inhibitor DMQD-CHO of the inhibitory action of IGF-1 on ceramide-depleted catalase. HL-60 cells were treated with

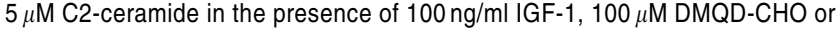
both $100 \mathrm{ng} / \mathrm{ml} \mathrm{IGF-1} \mathrm{and} 100 \mu \mathrm{M}$ DMQD-CHO for $24 \mathrm{~h}$. Measurement of catalase activity (B) and Western blotting analysis for catalase (B) were performed as described in Materials and Methods. The results $(\mathbf{A})$ are the averages from at least three independent experiments, and the bars indicate 1 S.D. The results (B) are the representative of two independent experiments. The significance of differences of catalase activity levels between the treatments was determined by ANOVA test. ${ }^{*}$ Indicates $P<0.01$ (B)

action of IGF-1 was suppressed by a PI-3 kinase inhibitor wortmannin or overexpression of dead PI-3 kinase (Figure 2). These results demonstrate that the anti-apoptotic effect of IGF-1 through PI-3 kinase is closely related to the inhibition of oxidative damage.

Regarding the mechanism by which ceramide inhibits IGF-1/ PI-3 kinase-dependent cell survival, it was previously reported that ceramide inhibited the activity or nuclear translocation of PKB/Akt kinase by causing dephosphorylation of serine 473 through inhibition of PI-3 kinasedependent kinase 2 or ceramide-activated protein phosphatase. ${ }^{23,24,34,35}$ Recently, modulation of caveolin-1 in microdomain of the membrane was also suggested to be involved in inhibition of Pl-3 kinase activation by ceramide. $^{25}$ In contrast, PI-3/Akt kinase inhibited stressinduced apoptosis without increasing ceramide generation. ${ }^{21,36}$ Interleukin-10 and interleukin-13 were also reported to inhibit pro-inflammatory cytokine-induced ceramide production through $\mathrm{PI}-3$ kinase. ${ }^{22}$ Here, we found 
that the amount of long-chain ceramide generated by $\mathrm{C} 2$ ceramide was not inhibited at all when IGF-1 inhibited C2ceramide-induced apoptosis (Figure 3), suggesting that IGF-1/PI-3 kinase inhibits apoptosis downstream of ceramide action rather than affecting stress-induced ceramide generation.

Insulin was shown to inhibit hydrogen peroxide-induced apoptosis through activating $\mathrm{PI}-3$ kinase,${ }^{37}$ but the present work seems to be the first report to show that IGF-1/PI-3 kinase inhibits an increase of oxidative damage downstream of ceramide action. Moreover, although it remains unproven, another important possibility suggested by the data in Figure 3 is that $\mathrm{C} 2$-ceramide might have an indirect effect, which is independent on a ceramide-mimicking action, on physiological ceramide generation.

It seems that oxidative damage and caspases are common pro-apoptotic signals involved in ceramideinduced apoptosis. This notion was supported by the report that apoptosis and ceramide generation were clearly inhibited by antioxidants, including GSH, NAC, catalase and $\mathrm{GPx},{ }^{6,9,38}$ or by caspase-3 inhibitors regardless of the kind of stress. ${ }^{39,40}$ Therefore, it would be important to investigate the mechanism by which IGF-1/PI-3 kinase inhibits ceramide-induced HL-60 cell apoptosis from the standpoint of the mechanistic connection between oxidative damage and caspase-3.

We here focused on whether IGF-1 affected the function of ROS scavenger catalase in a manner dependent on $\mathrm{PI}-3$ kinase. As shown in Figures 4 and 5, catalase depletion by C2-ceramide was restored by IGF-1 or PI-3 kinase overexpression at both protein and activity levels, while this restoration was suppressed by the addition of wortmannin. Moreover, a catalase inhibitor ATZ suppressed the inhibitory action of IGF-1 on ceramide-induced oxidative damage and apoptosis in a dose-dependent manner, while purified recombinant catalase augmented the same inhibition as shown in Figure 6. These results strongly suggest that IGF1/PI-3 kinase pathway inhibited ceramide-induced apoptosis by releasing oxidative damage through catalase function.

Ceramide was reported to activate caspase- 3 via cytosolic release of cytochrome $c$ from mitochondria and caspase-9 activation, resulting in induction of apoptosis. ${ }^{11,41}$ Although IGF-1 blocked apoptosis induction by inhibiting caspase-3 activation in retinal ganglion cells and cardiac muscle cells, ${ }^{16,20}$ the mechanistic connection between caspase- 3 activation and the increase of oxidative damage remains to be elucidated. How does IGF-1 affect ceramide-induced activation of caspase-3 to increase oxidative damage? IGF-1 inhibited ceramideinduced decrease of mitochondrial membrane potential, and release of cytosolic cytochrome $c$, cleavage of caspase- 3 and caspase- 3 activation, suggesting that the inhibition of caspase-3 via mitochondrial function might be the target of IGF-1 action (Figure 7). As shown in Table 1, ceramide-induced caspase-3, oxidative damage and apoptosis were suppressed by the pretreatment with a synthetic tetrapeptide DMQD-CHO, which is a specific inhibitor of caspase-3 designed from the cleaving site of protein kinase $\mathrm{C} \delta$ by caspase-3. ${ }^{13}$ These results indicated that caspase-3 is located upstream of the oxidative damage in
C2-ceramide-induced apoptosis. In addition, the restoration by IGF-1 of ceramide-depleted catalase was enhanced at both activity and protein levels in the presence of DMQD$\mathrm{CHO}$ (Figure 8). It has been reported that inhibition of hydrogen peroxide generation by catalase blocked apoptosis owing to a reduction of caspase- 3 activity, ${ }^{42,43}$ and that NO stimulated hydrogen peroxide production by affecting mitochondria function, and subsequently increased caspase-3 activity. ${ }^{44,45}$ However, the results we showed here, conversely, demonstrated that caspase-3 induced oxidative damage through inhibiting catalase function. Therefore, caspase-3 and oxidative damage may consist with the signalling cycle to enhance the induction of apoptosis.

Ceramide has been shown to inhibit anti-apoptotic signals such as Bcl-2 family, heat shock protein-70, diacylglycerol/protein kinase $\mathrm{C}$ system, PI-3 kinase and Akt kinase. 2,23,24,34,46 In contrast, we demonstrated here that the activation of IGF-1/PI-3 kinase inhibited ceramideinduced oxidative damage by preventing catalase function through caspase-3 inhibition, and consequently protected the cells from apoptotic death. The present findings suggest that the coordinated cross-talk between IGF-1/PI-3 kinase dependent survival signals and ceramide-induced proapoptotic signals such as oxidative damage and caspase3 is important in determining the fate of the cells.

\section{Materials and Methods}

\section{Materials}

Human leukemia HL-60 cells were a kind gift from Dr. M Saito (National Cancer Institute, Tokyo, Japan). [ $\left.\gamma-{ }^{32} \mathrm{P}\right]-\mathrm{ATP}(6000 \mathrm{Ci} / \mathrm{mmol})$ was purchased from Amersham Pharmacia Biotech (Buckinghamshire, UK). Recombinant human insulin-like growth factor-1 was obtained from Fujisawa Pharmaceutical Co.,Ltd (Osaka, Japan). Nacetylsphingosine (C2-ceramide) was obtained from Matreya, Inc (PA, USA). Anti-PI-3 kinase p85, anti-PI-3 kinase p110, anti-caspase-3, anti- $\beta$-actin, anti cytochrome $c$ and anti-catalase antibodies were purchased from Santa Cruz Biotechnology, Inc. (California, USA). Peroxidase- conjugated anti-rabbit immunoglobulin was purchased from TAGO, Inc. (Burlingame, USA). Cis-parinaric acid (PCA) was obtained from Pierce (Rockford, USA). PI-3 kinase expression vectors were a kind gift from Dr. A Klippel. ${ }^{47}$ Other chemicals, unless mentioned otherwise, were purchased from Sigma Co. Ltd. (St. Louis, USA).

\section{Cell culture}

Human myelogenous leukemia HL-60 cells were grown in RPMI 1640 medium (Nissui, Tokyo, Japan) supplemented with $10 \%$ fetal calf serum (FCS, JRH Biosciences) and kanamycin sulfate $(80 \mathrm{ng} / \mathrm{ml})$, and incubated at $37^{\circ} \mathrm{C}$ in a humidified atmosphere containing $5 \% \mathrm{CO}_{2} / 95 \%$ air. The cells were counted using a hemocytometer and the viability was always greater than $95 \%$ in all experiments as assayed by $0.025 \%$ Trypan blue dye exclusion. Before the experiments, the cells were washed with phosphate-buffered saline (PBS) and incubated overnight in serum-free RPMl 1640 medium at a concentration of $2 \times 10^{5}$ cells $/ \mathrm{ml}$, and then treated as described in the text. The experiments using transfectants were performed in 10\% FCS-containing media. 


\section{Measurement of number of apoptotic cells}

The cells were treated with C2-ceramide at various conditions, harvested and then fixed in $1 \%$ glutaraldehyde for $30 \mathrm{~min}$ at room temperature, and stained with DAPI (4',6-diamidino-2-phenylindole) as described before. ${ }^{48}$ At least 200 cells were counted under a fluorescent microscope in each determination, and the cells with nuclear condensation and fragmentation were judged as apoptotic cells. The results expressed as a percentage of the total cells that were positive for apoptotic feature. Control indicates no treatment.

\section{Detection of apoptosis by FACS}

To assess cells undergoing apoptosis the annexin $\mathrm{V}$ staining kit (BD PharMingen) was used. After treatment the cells were harvested in cold PBS, washed, and stained with $5 \mu \mathrm{l}$ of Annexin V-FITC in $100 \mu \mathrm{l}$ of $1 \times$ binding buffer (10 mM HEPES (pH 7.4), $140 \mathrm{mM} \mathrm{NaCl}$, and $25 \mu \mathrm{M} \mathrm{CaCl}_{2}$ ) for $15 \mathrm{~min}$ at room temperature in the dark, diluted in $400 \mu \mathrm{l} 1 \times$ binding buffer, and immediately subjected to FACS analysis (10000 events/sample).

\section{Measurement of lipid peroxidation and catalase activity}

Cis-parinaric acid (CPA) is a fluorescent poly-unsaturated fatty acid used as a probe to directly monitor lipid peroxidation. After treatment, the cells were washed with PBS twice and resuspended in $3 \mathrm{ml} \mathrm{RPMI}$ 1640 media without FCS, and then incubated with $5 \mu \mathrm{M} \mathrm{CPA}$ at $37^{\circ} \mathrm{C}$ in $5 \% \mathrm{CO}_{2} / 95 \%$ air for $30 \mathrm{~min}$. Fluorescence measurement was carried out using a spectrophotometer F-3000 (Hitachi) using $318 \mathrm{~nm}$ excitation and $420 \mathrm{~nm}$ emission filters. Catalase activity was assayed by measuring the kinetics of the loss of $\mathrm{H}_{2} \mathrm{O}_{2}$ as described previously. ${ }^{49}$ The cells at a concentration of $1 \times 10^{6} / \mathrm{ml}$ were washed with PBS twice and resuspended in a solution containing $0.3 \%$ Triton$\mathrm{X}, 50 \mathrm{mM}$ Tris- $\mathrm{HCl}$ (pH 7.5), $0.2 \mathrm{mM}$ phenylmethyl-sulfonyl fluoride and $0.5 \%$ acetyltrimethylammonium bromide. This cell suspension was subjected to freeze - thawing and sonication with a model UR-20P (Tomy Seiko, Japan). The sonicate was centrifuged at $12000 \times g$ for $15 \mathrm{~min}$. The supernatant was used as the cell lysate. The cell lysate was supplemented with phosphate buffer and $\mathrm{H}_{2} \mathrm{O}_{2}$ and loss of $\mathrm{H}_{2} \mathrm{O}_{2}$ was monitored at $240 \mathrm{~nm}$ using spectrophotometer.

\section{Ceramide quantitation}

After extracting the lipids according to the Bligh and Dyer method, ceramide levels in the cells were measured enzymatically by using $E$ coli diacylglycerol kinase (DGK), which converts ceramide and diacylglycerol to ceramide-1 phosphate and phosphatidic acid, respectively, and the amounts of ceramide were corrected by phospholipids phosphate as described elsewhere. ${ }^{50}$

\section{Western blot analysis}

The samples $(50 \mu \mathrm{g})$ were denatured by boiling in Laemmli's sample buffer for $5 \mathrm{~min}$, subjected to SDS-polyacrylamide gel electrophoresis using a $7.5 \%$ running gel, and electroblotted to an Immobilon-P Transfer Membrane (Millipore) as described. ${ }^{51}$ Non-specific binding was blocked by incubation of the membrane with PBS containing 5\% skim milk and $0.1 \%$ Tween 20 for more than $1 \mathrm{~h}$. Then the membrane was washed in PBS containing $0.1 \%$ Tween 20 (PBS-T) once for $15 \mathrm{~min}$ and once for $5 \mathrm{~min}$, and incubated with a 1:200 dilution of anti$\mathrm{PI}-3$ kinase p85, and anti-PI-3 kinase p110 and anti-cytochrome $c$ and anti-catalase or anti-caspase-3 antibody in PBS-T for $1 \mathrm{~h}$. The membrane was washed in PBS-T once for $15 \mathrm{~min}$ and once for $5 \mathrm{~min}$, and incubated with a 1:4000 dilution of peroxidase-conjugated anti-rabbit immunoglobulin in PBS-T for $1 \mathrm{~h}$. After washing the membrane three times for $5 \mathrm{~min}$ in PBS-T, detection was performed using ECL Western blotting detection reagents (Amersham) according to the manufacturer's protocol.

\section{Preparation of mitochondria and cytosol}

Cells $(1 \times 107)$ were washed with PBS, resuspended in five volumes of CFS buffer (220 mM mannitol, $68 \mathrm{mM}$ sucrose, $2 \mathrm{mM} \mathrm{NaCl}, 2.5 \mathrm{mM}$ $\mathrm{KH} 2 \mathrm{PO} 4,0.5 \mathrm{mM}$ EGTA, $2 \mathrm{mM} \mathrm{MgCl} 2,5 \mathrm{mM}$ pyruvate, $0.1 \mathrm{mM}$ PMSF, $10 \mathrm{mM}$ HEPES-NaOH, pH 7.4), and swollen on ice for $20 \mathrm{~min}$. Cells were disrupted by $10-15$ aspirations through a 22-gauge needle and centrifuged at $750 \times g$ for $5 \mathrm{~min}$ at $4^{\circ} \mathrm{C}$ to remove nuclei. The supernatant was centrifuged again $\left(10000 \times g, 10 \mathrm{~min}, 4^{\circ} \mathrm{C}\right)$ to recover mitochondria. The $10000 \times g$ supernatant was ultracentrifuged at $100000 \times g$ for $30 \mathrm{~min}$ at $4^{\circ} \mathrm{C}$, and the remaining supernatant was used as the cytosol fraction. Both samples were used immediately or stored at $-80^{\circ} \mathrm{C}$ until immunodetection of cytochrome $c$.

\section{Measurement of mitochondrial membrane potential}

Changes of mitochondrial membrane potential were studied with the use of $\mathrm{DiOC}_{6}$. $\mathrm{DiOC}_{6}$ is incorporated into mitochondria in strict nonlinear dependence to mitochondrial membrane potential and emits exclusively within the spectrum of green light. After treatment, $1 \times 10^{6}$ cells were treated continuously with $40 \mathrm{nM} \mathrm{DiOC}_{6}$ in the culture medium for $15 \mathrm{~min}$ at $37^{\circ} \mathrm{C}$. After treatment with $\mathrm{DiOC}_{6}$, the cells were washed twice with PBS, resuspended in $1 \mathrm{ml}$ of PBS, and analyzed with a flow cytometer (FACScan; Becton Dickinson, San Jose, CA, USA). The data were recorded with FL1 photomultiplier, and 10000 cells per sample were acquired in histograms using the data analysis program CELL Quest.

\section{Measurement of DEVDase activity}

The cells after each treatment were homogenized in lysis buffer containing $10 \mathrm{mM}$ HEPES/KOH (pH 7.4), $2 \mathrm{mM}$ EDTA, 0.1\% CHAPS, $5 \mathrm{mM}$ dithiothreitol (DTT), $1 \mathrm{mM}$ PMSF, $100 \mu \mathrm{M}$ pepstatin, $0.15 \mathrm{U} / \mathrm{ml}$ aprotinin, and $50 \mu \mathrm{g} / \mathrm{ml}$ leupeptin, and centrifuged at $10000 \times g$ for $10 \mathrm{~min}$. The supernatant was collected as an enzyme source and added to the reaction mixture (10\% sucrose, $10 \mathrm{mM} \mathrm{HEPES} / \mathrm{KOH}$ (pH 7.4), $5 \mathrm{mM}$ DTT, $0.1 \%$ CHAPS, and $10 \mu \mathrm{M}$ DEVD-MCA) which was followed by incubation at $25^{\circ} \mathrm{C}$ for $60 \mathrm{~min}$. Fluorescence was measured by a microplate reader (MTP-100F, Corona Electric, Japan) using $360 \mathrm{~nm}$ excitation and $450 \mathrm{~nm}$ emission filters. Concentrations of 7-amino-4-methyl-coumarin (AMC) liberated as a result of cleavage were calculated comparing with standard AMC solutions.

\section{Detection of caspase-3 activity by FACS}

The caspase- 3 activity was evaluated as the protease activity of caspase-3 by using the PhiPhiLux G1D2 kit (MBL, Nagoya, Japan). A substrate of PhiPhiLux G1D2, which can penetrate into the cell nucleus, is converted to the fluorescent form when it is cleaved by the protease activity of caspase-3. The assessment was performed according to the manufacturer's recommendations. Briefly, $\mathrm{HL}-60$ cells were incubated with $75 \mu \mathrm{l}$ of PhiPhiLux G1D2 for $1 \mathrm{~h}$ at $37^{\circ} \mathrm{C}$ in $5 \%$ 
$\mathrm{CO}_{2}$, and caspase-3 activity was analyzed by fluorescence-activated cell sorting caliber flow cytometry.

\section{Expression constructs and transfection}

The expression plasmid constructs used were the constructs for constitutively activated $\mathrm{PI}-3$ kinase (the catalytic $\mathrm{p} 110$ subunit of $\mathrm{PI}-3$ kinase, Myc-tagged at the C-terminus in pEF-Bos vector) and kinase dead PI-3 kinase (the catalytic p110 subunit, point-mutated at the ATP- binding site, Myc-tagged in pEF-Bos vector) which have been previously described. ${ }^{47} \mathrm{HL}-60$ cells were transiently transfected by the electroporation method. Fifty micrograms of expression plasmid cDNA were mixed with per $5 \times 10^{7}$ cells and the mixture was exposed to a high-voltage pulse ( $300 \mathrm{~V}, 960 \mu \mathrm{F}$ ) by using a Bio-Rad electroporation apparatus with a capacitor extender. The transfected cells were cultured in RPMI 1640 media supplemented with $20 \%$ fetal calf serum and kanamycin sulfate $(80 \mathrm{ng} / \mathrm{ml})$, and incubated at $37^{\circ} \mathrm{C}$ in a humidified atmosphere containing $5 \% \quad \mathrm{CO}_{2} / 95 \%$ air. Prior to experiments $48 \mathrm{~h}$ after transfection, the medium was replaced with $10 \%$ fetal calf serum, and then the cells were treated as described in the text.

\section{Measurement of PI-3 kinase enzymatic activity}

After treatment the cells $\left(1 \times 10^{7}\right)$ were lysed in $700 \mu$ l of lysis buffer (50 mM Tris- $\mathrm{HCl}$ (pH 7.6), 0.5\% TritonX-100, $300 \mathrm{mM} \mathrm{NaCl,} 5 \mathrm{mM}$ EDTA, $10 \mu \mathrm{g} / \mathrm{ml}$ leupeptin, $10 \mu \mathrm{g} / \mathrm{ml}$ aprotinin, $1 \mathrm{mM}$ PMSF, $1 \mathrm{mM}$ sodium orthovanadate), and then the lysates were subjected to immunoprecipitation with anti-PI 3 kinase (p85 $\alpha$ ) antibody. Immunoprecipitants were washed once with cold PBS, twice with washing buffer A $(0.5 \mathrm{M} \mathrm{LiCl}, 0.1 \mathrm{M}$ Tris- $\mathrm{HCl}(\mathrm{pH} 7.4))$, and once with washing buffer $\mathrm{B}(0.1 \mathrm{M}$ Tris- $\mathrm{HCl}(\mathrm{pH} 7.4), 0.1 \mathrm{M} \mathrm{NaCl}, 1 \mathrm{mM}$ EDTA), and then assayed for PI-3 kinase activity. Note: all wash solutions contained $0.2 \mathrm{mM}$ sodium orthovanadate. For protein immunoblot analysis using anti-p85 antibody, one-third of this immunoprecipitant mixture was electrophoresed on an SDSpolyacrylamide gel and the separated proteins were blotted onto an Immobilon-P Transfer Membrane (Millipore) as described. ${ }^{47}$ Immunoprecipitants were resuspended in $50 \mu \mathrm{l}$ of $\mathrm{Pl}-3$ kinase reaction buffer ( $30 \mathrm{mM}$ HEPES ( $\mathrm{pH} 7.4), 30 \mathrm{mM} \mathrm{MgCl} 2,200 \mu \mathrm{M}$ adenosine, $40 \mu \mathrm{M} \mathrm{ATP}$ ), and PI (final concentration $0.2 \mathrm{mg} / \mathrm{ml}$ ) was preincubated at $4{ }^{\circ} \mathrm{C}$ in this buffer for $20 \mathrm{~min}$. The kinase reaction was started by addition of $20 \mu \mathrm{Ci}\left[\gamma-{ }^{32} \mathrm{P}\right]-\mathrm{ATP}$, and after incubation at $30^{\circ} \mathrm{C}$ or $15 \mathrm{~min}$, the reaction was terminated by addition of $100 \mu \mathrm{l}$ of $1 \mathrm{~N} \mathrm{HCl}$. The lipid-containing organic phase was applied to oxalate-coated TLC plates and developed in chloroform $/ \mathrm{methanol} /$ water/ammonium hydroxide (60/47/11.3/2) and lipid species were visualized by autoradiography.

\section{Statistical examination}

Statistical significances in this work were calculated by Student's $t$-test and ANOVA test.

\section{Acknowledgements}

We thank Dr. A. Klippel for the kind gift of expression plasmids of PI-3 kinase. This work was supported by the grants of Japanese Ministry of Science, Education and Culture and Ono Pharmaceutical Co., Ltd. (to T Okazali).

\section{References}

1. Obeid LM and Hannun YA (1995) Ceramide: a stress signal and mediator of growth suppression and apoptosis. J. Cell Biochem. 58: 191-198

2. Okazaki T, Kondo T, Kitano T and Tashima M (1998) Diversity and complexity of ceramide signalling in apoptosis. Cell Signal. 10: 685-692

3. Quillet-Mary A, Jaffrezou JP, Mansat V, Bordier C, Naval J and Laurent G (1997) Implication of mitochondrial hydrogen peroxide generation in ceramide-induced apoptosis. J. Biol. Chem. 272: 21388-21395

4. Degli Esposti Mand McLennan H (1998) Mitochondria and cells produce reactive oxygen species in virtual anaerobiosis: relevance to ceramide-induced apoptosis. FEBS Lett. 430: 338-342

5. Garcia-Ruiz C, Colell A, Mari M, Morales A and Fernandez-Checa JC. (1997) Direct effect of ceramide on the mitochondrial electron transport chain leads to generation of reactive oxygen species. Role of mitochondrial glutathione. J. Biol. Chem. 272: $11369-11377$

6. Kiryu-Seo S, Sasaki M, Yokohama H, Nakagomi S, Hirayama T, Aoki S, Wada K and Kiyama $H$ (2000) Damage-induced neuronal endopeptidase (DINE) is a unique metallopeptidase expressed in response to neuronal damage and activates superoxide scavengers. Proc. Natl. Acad. Sci. USA 97: 4345-4350

7. Davis MA, Flaws JA, Young M, Collins K and Colburn NH (2000) Effect of ceramide on intracellular glutathione determines apoptotic or necrotic cell death of JB6 tumor cells. Toxicol. Sci. 53: 48-55

8. Mansat de Mas V, Bezombes C, Quillet Mary A, Bettaieb A, D'Orgeix AD, Laurent $G$ and Jaffrezou JP (1999) Implication of radical oxygen species in ceramide generation, c Jun N-terminal kinase activation and apoptosis induced by daunorubicin. Mol. Pharmacol. 56: 867-874

9. Liu B and Hannun YA (1997) Inhibition of the neutral magnesium-dependent sphingomyelinase by glutathione. J. Biol. Chem. 272: 16281-16287

10. Zou H, Henzel WJ, Liu X, Lutschg A and Wang X (1997) Apaf-1, a human protein homologous to $\mathrm{C}$. elegans CED-4, participates in cytochrome c-dependent activation of caspase-3 [see comments]. Cell 90: 405-413

11. Anjum R, Ali AM, Begum Z, Vanaja J and Khar A (1998) Selective involvement of caspase-3 in ceramide induced apoptosis in AK-5 tumor cells. FEBS Lett. 439: $81-84$

12. Kondo T, Matsuda T, Kitano T, Takahashi A, Tashima M, Ishikura H, Umehara H, Domae N, Uchiyama T and Okazaki T (2000) Role of c-jun expression increased by heat shock- and ceramide-activated caspase- 3 in HL-60 cell apoptosis. Possible involvement of ceramide in heat shock-induced apoptosis. J. Biol. Chem. 275: $7668-7676$

13. Hirata H, Takahashi A, Kobayashi S, Yonehara S, Sawai H, Okazaki T, Yamamoto K and Sasada M (1998) Caspases are activated in a branched protease cascade and control distinct downstream processes in Fas-induced apoptosis. J. Exp. Med. 187: 587-600

14. Matsura T, Kai M, Fujii Y, Ito Hand YamadaK(1999)Hydrogen peroxide-induced apoptosis in HL-60 cells requires caspase-3activation. Free Radic. Res. 30:7383

15. Ma Y, Ogino T, Kawabata T, Li J, Eguchi K and Okada S (1999) Cupric nitrilotriacetate-induced apoptosis in HL-60 cells association with lipid peroxidation, release of cytochrome $C$ from mitochondria, and activation of caspase-3. Free Radic. Biol. Med. 27: 227-233

16. Wu W, Lee WL, Wu YY, Chen D, Liu T, Jang A, Sharma PM and Wang PH (2000) Expression of constitutively active phosphatidylinositol 3 kinase inhibits activation of caspase 3 and apoptosis of cardiac muscle cells. J. Biol. Chem. 275: 40113-40119

17. Mooney A, Jobson T, Bacon R, Kitamura M and Savill J (1997) Cytokines promote glomerular mesangial cell survival in vitro by stimulus-dependent inhibition of apoptosis. J. Immunol. 159: 3949-3960

18. Parrizas M, Saltiel AR and LeRoith D (1997) Insulin-like growth factor 1 inhibits apoptosis using the phosphatidylinositol 3 '-kinase and mitogen-activated protein kinase pathways. J. Biol. Chem. 272: 154-161

19. D'Ambrosio C, Ferber A, ResnicoffMand Baserga R(1996) A soluble insulin-like growth factor I receptor that induces apoptosis of tumor cells in vivo and inhibits tumorigenesis. Cancer Res. 56: 4013-4020

20. Kermer P, Klocker N, Labes M and Bahr M (2000) Insulin-like growth factor-I protects axotomized rat retinal ganglion cells from secondary death via PI3-Kdependent Akt phosphorylation and inhibition of caspase-3 In vivo. J. Neurosci. 20: $2-8$ 
21. Burow ME, Weldon CB, Collins Burow BM, Ramsey N, McKee A, Klippel A McLachlan JA, Clejan S and Beckman BS (2000) Cross-talk between phosphatidylinositol 3-kinase and sphingomyelinase pathways as a mechanism for cell survival/death decisions. J. Biol. Chem. 275: 9628-9635

22. Pahan K, Khan M and Singh I (2000) Interleukin-10 and interleukin-13 inhibit proinflammatory cytokine-induced ceramide production through the activation of phosphatidylinositol 3-kinase. J. Neurochem. 75: 576-582

23. Zhou H, Summers SA, Birnbaum MJ and Pittman RN (1998) Inhibition of Akt kinase by cell-permeable ceramide and its implications for ceramide-induced apoptosis. J. Biol. Chem. 273: 16568-16575

24. Schubert KM, Scheid MP and Duronio V (2000) Ceramide inhibits protein kinase B/Akt by promoting dephosphorylation of serine 473. J. Biol. Chem. 275:1333013335

25. Zundel W, Swiersz LM and Giaccia A (2000) Caveolin 1-mediated regulation of receptor tyrosine kinase-associated phosphatidylinositol 3-kinase activity by ceramide. Mol. Cell. Biol. 20: 1507-1514

26. Juin P, Hueber AO, Littlewood T and Evan G (1999) c-Myc-induced sensitization to apoptosis is mediated through cytochrome crelease. Genes Dev. 13: 13671381

27. LeverrierY, Thomas J, Mathieu AL, Low W, BlanquierB and Marvel J (1999) Role of PI3-kinase in Bcl-X induction and apoptosis inhibition mediated by IL-3 or IGF1 in Baf 3 cells. Cell Death Differ. 6: 290-296

28. Pass HI, Mew DJ, Carbone M, Matthews WA, Donington JS, Baserga R, Walker CL, Resnicoff M and Steinberg SM (1996) Inhibition of hamster mesothelioma tumorigenesis by an antisense expression plasmid to the insulin-like growth factor-1 receptor. Cancer Res. 56: 4044-4048

29. Estrov Z, Meir R, Barak Y, Zaizov R and Zadik Z (1991) Human growth hormone and insulin-like growth factor-1 enhance the proliferation of human leukemic blasts. J. Clin. Oncol. 9: 394-399

30. Kalinich JF, Ramakrishnan R, McClain DE and Ramakrishnan N (2000) 4Hydroxynonenal, an end-product of lipid peroxidation, induces apoptosis in human leukemic T- and B-cell lines. Free Radic. Res. 33: 349-358.

31. Bohler T, Waiser J, Hepburn H, Gaedeke J, Lehmann C, Hambach P, Budde K and Neumayer HH (2000) TNF-alpha and IL-1alpha induce apoptosis in subconfluent rat mesangial cells. Evidence for the involvement of hydrogen peroxide and lipid peroxidation as second messengers. Cytokine. 12: 986-991

32. Manna SK, Mukhopadhyay A and Aggarwal BB (2000) Resveratrol suppresses TNF induced activation of nuclear transcription factors NF-kappa B, activator protein-1, and apoptosis: potential role of reactive oxygen intermediates and lipid peroxidation. J. Immunol. 164: 6509-6519

33. Wei T, Chen C, Hou J, Zhao B, Xin W and Mori A (1999) The antioxidant EPC-K1 attenuates NO-induced mitochondrial dysfunction, lipid peroxidation and apoptosis in cerebellar granule cells. Toxicology 134: 117-126

34. Schmitz-Peiffer C, Craig DL and Biden TJ (1999) Ceramide generation is sufficient to account for the inhibition of the insulin-stimulated PKB pathway in C2C12 skeletal muscle cells pretreated with palmitate. J. Biol. Chem. 274: 24202-24210

35. Salinas M, Lopez-Valdaliso R, Martin D, Alvarez A and Cuadrado A (2000) Inhibition of $\mathrm{PKB} / \mathrm{Akt} 1$ by $\mathrm{C} 2$-ceramide involves activation of ceramide-activated protein phosphatase in PC12 cells. Mol. Cell. Neurosci. 15: 156-169

36. Goswami R, Kilkus J, Dawson SA and Dawson G (1999) Overexpression of Akt (protein kinase $B$ ) confers protection againstapoptosis and prevents formation of ceramide in response to pro-apoptotic stimuli. J. Neurosci. Res. 57: 884-893

37. Aikawa R, Nawano M, Gu Y, Katagiri H, Asano T, Zhu W, Nagai R and Komuro I (2000) Insulin prevents cardiomyocytes from oxidative stress-induced apoptosis through activation of $\mathrm{PI} 3$ kinase/Akt. Circulation 102: 2873-2879

38. Liu B, Andrieu-Abadie N, Levade T, Zhang P, Obeid LM and Hannun YA (1998) Glutathione regulation of neutral sphingomyelinase in tumor necrosis factoralpha induced cell death. J. Biol. Chem. 273: 11313-11320
39. Janicke RU, Sprengart ML, Wati MR and Porter AG (1998) Caspase-3 is required for DNA fragmentation and morphological changes associated with apoptosis. J. Biol. Chem. 273: 9357-9360

40. Ohta T, Kinoshita T, Naito M, Nozaki T, Masutani M, Tsuruo T and Miyajima A (1997) Requirement of the caspase-3/CPP32 protease cascade for apoptotic death following cytokine deprivation in hematopoietic cells. J. Biol. Chem. 272: 23111-23116

41. Yoshimura S, Banno Y, Nakashima S, Takenaka K, Sakai H, Nishimura Y, Sakai N, Shimizu S, Eguchi Y, Tsujimoto Y and Nozawa Y (1998) Ceramide formation leads to caspase-3 activation during hypoxic PC12 cell death. Inhibitory effects of $\mathrm{Bcl}-2$ on ceramide formation and caspase-3 activation. J. Biol. Chem. 273: $6921-6927$

42. Chen YC, Lin-Shiau SY and Lin JK (1998) Involvement of reactive oxygen species and caspase 3 activation in arsenite-induced apoptosis. J. Cell. Physiol. 177: $324-333$

43. Sengupta J, Sinha P, Mukhopadhyay C and Ray PK (1999) Molecular modeling and experimental approaches toward designing a minimalist protein having Fcbinding activity of Staphylococcal protein A. Biochem. Biophys. Res. Commun. 256: $6-12$

44. Rossig L, Fichtlscherer B, Breitschopf K, Haendeler J, Zeiher AM, Mulsch A and Dimmeler S (1999) Nitric oxide inhibits caspase-3 by S-nitrosation in vivo. J. Biol. Chem. 274: 6823-6826

45. Yabuki M, Kariya S, Ishisaka R, Yasuda T, Yoshioka T, Horton AA and Utsumi K (1999) Resistance to nitric oxide-mediated apoptosis in $\mathrm{HL}-60$ variant cells is associated with increased activities of $\mathrm{Cu}, \mathrm{Zn}$-superoxide dismutase and catalase. Free Radic. Biol. Med. 26: 325-332

46. Esposti MD, Hatzinisiriou I, McLennan H and Ralph S (1999) Bcl-2 and mitochondrial oxygen radicals. New approaches with reactive oxygen speciessensitive probes. J. Biol. Chem. 274: 29831-29837

47. Klippel A, Reinhard C, Kavanaugh WM, Apell G, Escobedo MA and Williams LT (1996) Membrane localization of phosphatidylinositol 3-kinase is sufficient to activate multiple signal-transducing kinase pathways. Mol. Cell. Biol. 16: 41174127

48. Kondo T, Matsuda T, Tashima M, Umehara H, Domae N, Yokoyama K, Uchiyama Tand Okazaki T (2000) Suppression of heat shock protein-70 by ceramide in heat shock induced HL-60 cell apoptosis. J. Biol. Chem. 275: 8872-8879

49. Beers RF and Sizer IW (1952) A spectrophotometric method for measuring the break down of hydrogen peroxide by catalase. J. Biol. Chem. 195: 133-140

50. Okazaki T, Bielawska A, Bell RM and Hannun YA (1990) Role of ceramide as a lipid mediator of 1 alpha,25-dihydroxyvitamin D3-induced HL-60 cell differentiation. J. Biol. Chem. 265: 15823-15831

51. Sawai H, Okazaki T, Yamamoto H, Okano H, Takeda Y, Tashima M, Sawada H, Okuma M, Ishikura H, Umehara Hetal, (1995) Requirement of AP-1 for ceramide induced apoptosis in human leukemia HL-60 cells. J. Biol. Chem. 270: 27326 27331

52. Demura Y, Ameshima S, Ishizaki T and Miyamori I (1999) [Glutathione peroxidase]. Nippon Rinsho. 57: 448-450

53. Xia YM, Hill KE and Burk RF (1989) Biochemical studies of a selenium-deficient population in China: measurement of selenium, glutathione peroxidase and other oxidant defense indices in blood. J. Nutr. 119: 1318-1326

54. Takahashi A, Alnemri ES, Lazebnik YA, Fernandes-Alnemri T, Litwack G, Moir RD, Goldman RD, Poirier GG, Kaufmann SHand EarnshawWC (1996) Cleavage of lamin A by Mch2 alpha but not CPP32: multiple interleukin 1 beta-converting enzyme-related proteases with distinct substrate recognition properties are active in apoptosis. Proc. Natl. Acad. Sci. USA 93: 8395-8400 